\title{
Pattern of milk yield and immunoglobulin concentration and factors associated with colostrum quality at the quarter level in dairy cows after parturition
}

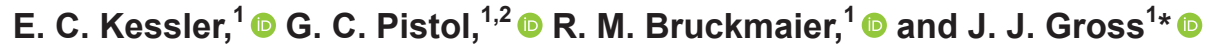 \\ ${ }^{1}$ Veterinary Physiology, Vetsuisse Faculty, University of Bern, CH-3012 Bern, Switzerland \\ ${ }^{2}$ Laboratory of Animal Biology, National Institute for Research and Development in Animal Biology and Nutrition, Balotesti, 077015 IIfov, Romania
}

\begin{abstract}
First colostrum yield and constituents as well as milk yield during established lactation vary considerably among mammary quarters in dairy cows. However, data on the development of milk yield, IgG concentration, and their distribution per quarter within cows during the first milkings after calving are scarce. We analyzed milk production and IgG concentration at the individual quarter level in 29 multiparous Holstein cows during the first 5 milkings after calving. Cow- and calf-related factors (time interval between calving and first milking, parity number, previous lactation yield, gestation length, dry period length, sex, and birth weight of the calf) potentially affecting first colostrum quality and quantity were assessed. Milking of first colostrum was carried out between 30 and 180 min after parturition. Further milkings were performed twice daily. Quarter milk yield varied between 0.1 and $5.5 \mathrm{~kg}$ at the first milking and between 1.4 and $5.1 \mathrm{~kg}$ at the fifth milking relative to parturition. Quarter IgG concentration ranged between 18.8 and $106.0 \mathrm{mg} / \mathrm{mL}$ at the first milking and between 0.8 and $46.1 \mathrm{mg} / \mathrm{mL}$ at the fifth milking. Distribution of milk yield and IgG concentration among quarters was not entirely repeatable during the first 5 successive milkings after parturition; that is, the ranking of quarters changed (intraclass correlation coefficients for quarter milk yield and $\operatorname{IgG}$ concentration: 0.64 and 0.79 , respectively). The average hourly milk production increased in all quarters, ranging from 0.02 to $0.26 \mathrm{~kg} / \mathrm{h}$ between the first 2 milkings up to 0.11 to $0.45 \mathrm{~kg} / \mathrm{h}$ between the fourth and fifth milkings. First colostrum yield was not affected by any of the evaluated cow- and calf-related factors. Quarter colostrum IgG concentration was higher in cows with a higher
\end{abstract}

Received July 18, 2019.

Accepted September 3, 2019.

*Corresponding author: josef.gross@vetsuisse.unibe.ch previous lactation yield, whereas a lower colostrum IgG content was observed in cows with a longer gestation period and consequently heavier calves. In conclusion, milk yield and IgG concentration of individual quarters varied considerably, and their distribution among quarters within cows was moderately repeatable in consecutive milkings and changed partially over time. The decline of $\operatorname{IgG}$ concentration was independent of the concomitant increase in milk secretion, with changes occurring at different rates in individual quarters. Our results confirm the independence of the single mammary quarters at the onset of lactation despite an identical exposure to endocrine stimuli.

Key words: quarter, colostrum, milk yield, immunoglobulin G, onset of lactation

\section{INTRODUCTION}

Newborn ungulates such as ruminants rely on the ingestion of a sufficient amount of good-quality colostrum to acquire passive immunization and thus protection against infectious diseases. Due to the importance of first colostrum for calves' health, previous research investigated factors affecting first colostrum IgG content to improve colostrum quality. As reviewed by Quigley and Drewry (1998) and Weaver et al. (2000), factors such as interval between calving and milking, age of the dam, dry period length, or calving season may affect colostral IgG concentrations. Colostrum quality and quantity at the first milking vary distinctly between cows, herds, and regions (Baumrucker et al., 2010; Morrill et al., 2012) but also between quarters within cows (Baumrucker et al., 2014a; Gross et al., 2017). Considerable differences among quarters in terms of colostral components such as IgG are well documented (Baumrucker et al., 2014a; Samarütel et al., 2016). We recently described the variation in first colostrum yield and distribution among quarters in consecutive lactations in primi- and multiparous dairy cows (Gross et al., 2016). During established lactation, the hindquarters were shown to produce more milk compared with the 
front quarters (Rothschild et al., 1980; Rothenanger et al., 1995).

The evaluation of factors explaining and contributing to quarter variation in dairy cows was occasionally done in mid- to late-lactating cows or restricted to studies with first colostrum milking. However, none of the earlier investigations on quarter colostrum variation extended their analyses to include the very first days of lactation after colostrum harvest. Therefore, the aim of the present study was to investigate the variation of milk yield and IgG concentration and their distributions among quarters within cows during the first 5 milkings after parturition. Furthermore, we revisited characteristics of the previous lactation and current pregnancy (e.g., parity number, previous lactation yield, dry period length) that were earlier described to affect colostrum quality and quantity in order to examine their contribution to respective quarter variation.

\section{MATERIALS AND METHODS}

\section{Animals, Milk Sampling, and Analysis}

The animal trial was approved by the Veterinary Office of the Canton Fribourg, Switzerland, and conducted in accordance with the guidelines of the Swiss Law on Animal Protection. Twenty-nine multiparous Holstein dairy cows (parity $2.8 \pm 1.0$; mean $\pm \mathrm{SD}$ ) housed on a research farm were enrolled in this study. Previous lactation yield was $7,958 \pm 1,532 \mathrm{~kg}$, and the dry period length averaged $64.4 \pm 14.3 \mathrm{~d}$ (mean $\pm \mathrm{SD}$ ). Approximately 1 wk before expected calving, cows were moved to straw-bedded calving pens and were kept there during the first $3 \mathrm{~d}$ after parturition. The diet of dry cows consisted of hay ad libitum, $1 \mathrm{~kg}$ of cereal-based concentrate, and $0.5 \mathrm{~kg}$ of a mineral supplement. After parturition, the amount of concentrate was increased to $2.5 \mathrm{~kg}$, and the mineral feed was adapted for lactating cows. Time of calving was closely monitored by farm staff and video cameras. Immediately after parturition, calves were separated from their dams to prevent suckling. Cows were milked for the first time between 30 and 180 min after parturition with a portable quarter-milking machine with the capacity for each udder quarter to be collected into a separate container. Thereafter, cows were milked twice daily at regular milking times (0530 and $1630 \mathrm{~h}$ ) and further quarter milk samples were taken from the 4 subsequent milkings. The interval between the first and second milkings ranged from 3.5 to $18.5 \mathrm{~h}(10.4 \pm 3.9 \mathrm{~h}$; mean \pm SD). Milk yield was recorded individually for each quarter at each milking, and milk samples $(\sim 50$
$\mathrm{mL}$ /quarter) were frozen at $-20^{\circ} \mathrm{C}$ until analysis of total IgG content.

Total IgG was measured in each quarter milk sample using a modified ELISA (Bovine IgG ELISA Quantitation Set; catalog no. E10-118; Bethyl Laboratories Inc., Montgomery, TX) as previously described (Lehmann et al., 2013). Samples were thawed at room temperature and serially diluted in ELISA wash buffer $(50 \mathrm{mM}$ Tris, $0.14 M \mathrm{NaCl}, 0.05 \%$ Tween 20 , adjusted to $\mathrm{pH}$ 8.0) to final dilutions of $1: 400,000$ and $1: 800,000$. The interassay coefficient of variation was $<5.5 \%$, and the intra-assay coefficient of variation was $<8.5 \%$. Results were expressed as IgG concentration in milligrams per milliliter of milk.

\section{Statistical Analysis}

The statistical software package SAS (version 9.4; SAS Institute Inc., Cary, NC) was used to perform statistical analysis. Data were checked for normal distribution using the UNIVARIATE procedure of SAS. The presented data are means \pm standard error of the mean except where denoted as standard deviation. Cow- and calf-related parameters (time interval between calving and first milking, parity number, previous lactation yield, gestation length, dry period length, sex and birth weight of the calf) assumed to affect quarter colostrum yield and colostral IgG concentration were evaluated with the GLM procedure with quarter position as fixed effect and the individual cow as random subject. Significance of relationships between aforementioned parameters was estimated with the Tukey-corrected $t$-test. Changes in the increase and distribution of milk yield and the decline of IgG concentration at the quarter level over the first 5 milkings after parturition were investigated using a MIXED model with milking number, quarter, and milking number $\times$ quarter interaction as fixed effects and the individual cow as random subject. Effects were considered significant at $P<0.05$. The covariance parameters $\left(\sigma^{2}\right)$ generated by this mixed model encoded as a 3-level random intercept model, which corrected for clustering at the level of the cow and the milking number, were used to calculate the intraclass correlation coefficient (ICC) for milk yield and $\operatorname{IgG}$ concentration at the quarter level. The ICC was calculated as follows: ICC $=\sigma_{\text {quarter }}^{2} /\left(\sigma_{\text {cow }}^{2}\right.$ $+\sigma_{\text {quarter }}^{2}$. The ICC values here quantify the repeatability of measurements between quarters within a cow during successive milkings. For instance, an ICC of 0.70 indicates that $70 \%$ of measurements are repeatable in terms of their ranking among individual quarters during successive milkings. 


\section{RESULTS AND DISCUSSION}

\section{Colostrum Quality and Yield at the Quarter Level and Associations with Cow- and Calf- Related Factors}

Colostrum yield and IgG concentration per quarter at the first milking after parturition varied considerably, ranging from 0.1 to $5.5 \mathrm{~kg}$ and from 18.8 to 106.0 $\mathrm{mg} / \mathrm{mL}$, respectively (Figures $1 \mathrm{~A}$ and $1 \mathrm{~B}$ ). The present study confirms the variation in first colostrum yield and $\operatorname{IgG}$ concentration of individual mammary quarters of our previous investigations (Gross et al., 2016). A greater amount of colostrum is often assumed to be associated with reduced immunoglobulin concentration
(Kehoe et al., 2007; Conneely et al., 2013; Cabral et al., 2016). However, in the present study, first colostrum IgG concentration was not affected by colostrum yield. The wide variation of quarter colostrum yield in our study (Table 1) confirms earlier results of Baumrucker et al. (2010). Hence, first colostrum yield does not represent a reliable criterion to evaluate colostrum quality in terms of its IgG content, especially when considering the tremendous variation in quarter IgG concentrations (Figure 1B; Gross et al., 2017). Several factors such as interval between calving and first milking, parity of the dam, and dry period length were reported to affect colostrum quantity and quality (Gulliksen et al., 2008; Conneely et al., 2013; Cabral et al., 2016)
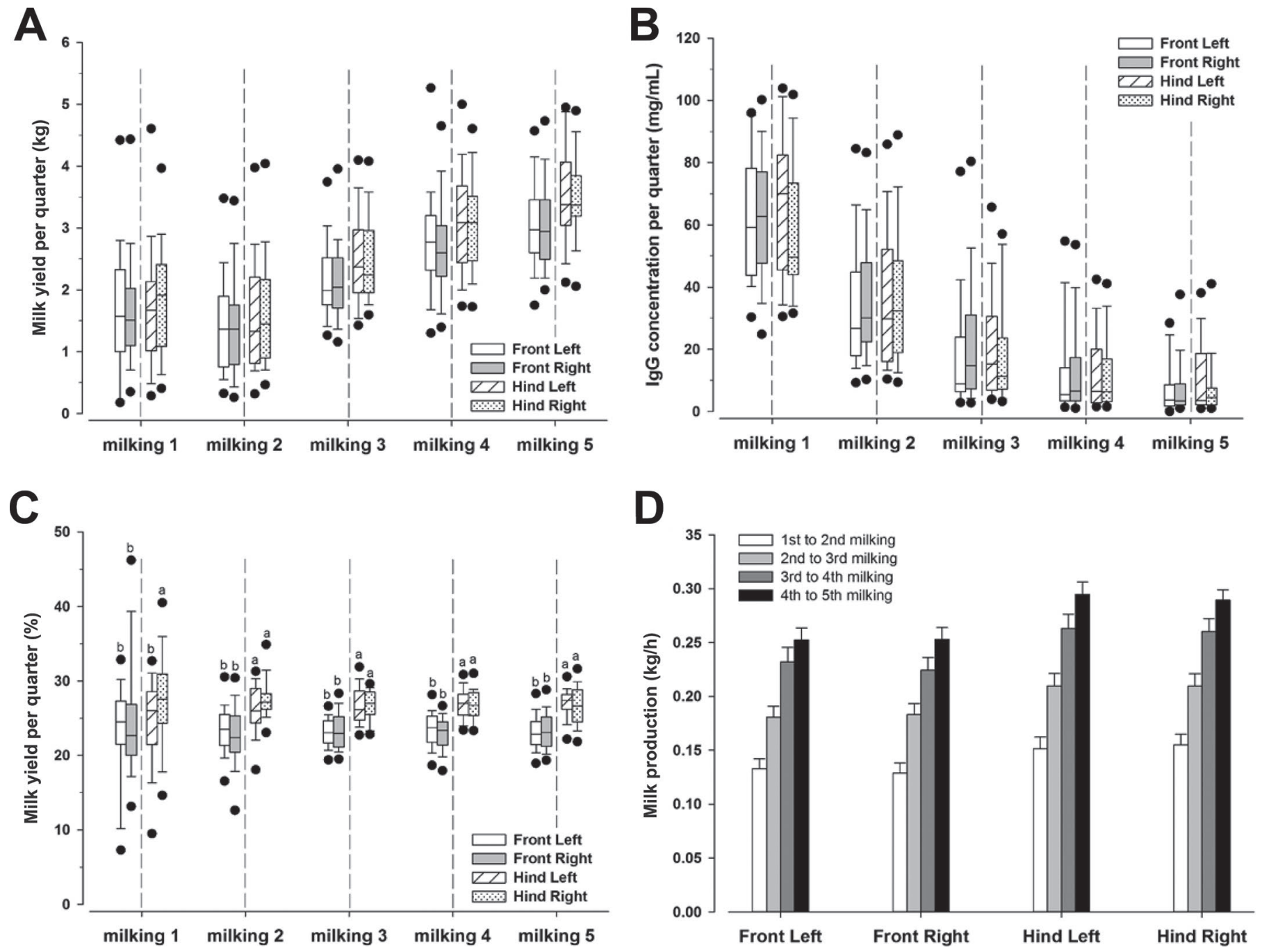

Figure 1. Development of quarter milk yield (A) and total IgG concentration (B) and distribution of milk yields per quarter (C) during the first 5 milkings after parturition. (D) Hourly milk production since the respective previous milking from the second to the fifth milking after parturition is shown as mean value \pm SEM. The boxes in panels $\mathrm{A}, \mathrm{B}$, and $\mathrm{C}$ indicate the 25 th to 75 th quartiles, whereas the whiskers show the 5th to 95th percentile distribution of the data. The line within the box represents the median of the data. Differences between the quarter distributions of milk yields (\%) within milkings are indicated by different letters (a, b; $P<0.05$ ). 
Table 1. Cow- and calf-related parameters and their effect on quarter colostrum yield and colostral IgG concentration in 29 multiparous dairy cows

\begin{tabular}{|c|c|c|c|c|c|c|}
\hline \multirow[b]{2}{*}{ Parameter } & \multirow[b]{2}{*}{ Mean } & \multirow[b]{2}{*}{ SD } & \multirow[b]{2}{*}{ Minimum } & \multirow[b]{2}{*}{ Maximum } & \multicolumn{2}{|c|}{$P$-value } \\
\hline & & & & & $\begin{array}{l}\text { Effect on } \\
\text { colostrum yield }\end{array}$ & $\begin{array}{l}\text { Effect on IgG } \\
\text { concentration }\end{array}$ \\
\hline IgG concentration $(\mathrm{mg} / \mathrm{mL})$ & 61.9 & 20.9 & 18.8 & 106.0 & 0.06 & - \\
\hline $\begin{array}{l}\text { Time interval between calving } \\
\text { and first milking (min) }\end{array}$ & 88.4 & 49.0 & 30 & 180 & 0.80 & 0.002 \\
\hline Dry period length (d) & 64.4 & 14.3 & 43 & 97 & 0.17 & 0.15 \\
\hline Gestation length (d) & 284.1 & 3.7 & 276 & 290 & 0.80 & $<0.0001$ \\
\hline Calf sex & - & - & - & - & 0.93 & 0.18 \\
\hline Calf birth weight (kg) & 44.5 & 5.0 & 36 & 57 & 0.30 & 0.001 \\
\hline
\end{tabular}

but did not provide an explanation for the variation at quarter level. Cows enrolled in the present experiment were milked in a very narrow interval between 30 and 180 min after calving (Table 1), whereas in previous studies first milking was performed between 0.3 and $24 \mathrm{~h}$ after parturition (Morin et al., 2010; Conneely et al., 2013; Cabral et al., 2016). According to these authors, timing of the first milking did not negatively influence colostrum volume and IgG concentration up to 9 to $12 \mathrm{~h}$ postpartum. Despite the very narrow time frame (maximum of $180 \mathrm{~min}$ until first milking after parturition), IgG concentration of first colostrum in the present study was even higher in cows milked later (i.e., $3 \mathrm{~h}$ after calving) compared with cows milked very close to calving (30 min postpartum; $P<0.01$; Table 1 ). The present results confirm our recent evaluations that colostrogenesis (i.e., secretion of IgG into colostrum) does not cease at parturition and that transfer of $\operatorname{IgG}$ into colostrum continues and is even accelerated during the first few hours after calving (Gross et al., 2014; Baumrucker et al., 2016). In contrast, first colostrum yield was not affected by the interval between parturition and first milking $(P=0.80$; Table 1$)$. This observation might be attributed to cows' individual variation in colostrum production on the one hand and the short calving-milking interval (maximum $3 \mathrm{~h}$ ) on the other hand. Although colostrogenesis continues, lactogenesis (i.e., onset of milk secretion and volume production) appears to lag behind. Associations with endocrine changes such as estrogen, prolactin, and progesterone require further investigation.

It is well documented that colostral immunoglobulin concentrations (Gulliksen et al., 2008; Cabral et al., 2016; Gross et al., 2017) and colostrum yield (Conneely et al., 2013; Kessler et al., 2014; Gross et al., 2017) are greater in older compared with younger cows. However, IgG concentration $(P=0.53$; Table 1$)$ and quarter co- lostrum yield $(P=0.17)$ were not affected by the parity of the dam in our trial, likely due to the absence of primiparous cows. In agreement with previous research (Cabral et al., 2016; Dunn et al., 2017), we found greater IgG concentrations in first colostrum of cows with a higher previous lactation yield $(P<0.05$; Table 1). Cabral et al. (2016) attributed this observation to improved nutrition and management status in highproducing dairy herds. In the current study, cows were kept under identical conditions, thus suggesting that, in particular, the broad variation in individual previous lactation yields $(5,099-10,569 \mathrm{~kg} / 305 \mathrm{~d})$ accounts for the concomitant variation of colostral immunoglobulin content. The mammary gland's ability to produce milk is mainly determined by the number of epithelial cells and their differentiation status (Boutinaud et al., 2004; Davis, 2017). More secretory cells likely enable the transcytosis of more IgG into colostrum, which explains the greater IgG content in colostrum of cows with a higher previous lactation yield. Colostrum yield, however, was not influenced by the previous lactation yield $(P=0.20$; Table 1$)$. Lactogenesis can therefore be assumed not to be fully active and to vary greatly in the first hours after parturition. In other reports (e.g., Morin et al., 2010; Conneely et al., 2013; Cabral et al., 2016), cows were milked for the first time up to $24 \mathrm{~h}$ after calving, and potential dilution effects of the increasing milk production on IgG content can be expected. The greater amount of IgG transferred into colostrum in cows with a higher milk production in our study was apparently not subjected to a dilution effect due to the concomitantly greater colostrum production. Furthermore, our results confirm that colostrogenesis and especially the resulting colostrum volume are variable and independent of the cow milk production potential of the overall lactation period (Kessler et al., 2014; Cabral et al., 2016). 
The nonlactating period enables the renewal of milk epithelial cells in the mammary gland by their partial replacement and cell proliferation processes (Capuco et al., 1997; Annen et al., 2008). The optimal length of the dry period in terms of colostrum quality and quantity is controversial. In line with previous work (Shoshani et al., 2014; Mayasari et al., 2015; Cabral et al., 2016), dry period length was not associated with colostral IgG concentration $(P=0.15$; Table 1$)$ and quarter colostrum yield $(P=0.17)$ in our study, whereas other authors described a positive effect of an 8-wk dry period compared with a shortened dry period on colostrum quality (Watters et al., 2008; Dunn et al., 2017) and yield (Mayasari et al., 2015). However, dry period lengths in the present study were at least $6 \mathrm{wk}$ for all cows. Totally omitting the dry period resulted in slightly poorer colostrum quality and less yield after calving as IgG-rich secretions were removed in continuously milked cows before parturition (Baumrucker et al., 2014b). Gestation length varies among and within dairy breeds and is associated with sex and weight of the calf (Norman et al., 2009; Dhakal et al., 2013; Kamal et al., 2014). However, the literature examining the relationships between colostrum traits, gestation length, and characteristics of calves turned out to be scarce. In accordance with an earlier study by Cabral et al. (2016), calf sex was not associated with colostral immunoglobulin concentration in the present investigation $(P=0.18$; Table 1$)$ or with colostrum volume $(P$ $=0.93)$. Calf weight did not affect colostrum yield $(P=$ 0.30 ; Table 1 ), in contrast to results presented by Conneely et al. (2013) indicating higher colostrum yields with increasing calf weight. Surprisingly, our evaluations revealed that IgG concentration in colostrum was negatively associated with calf birth weight $(P=0.001)$ and the related gestation length $(P<0.0001)$, implying that a longer duration of gestation is not necessarily beneficial for the colostral IgG content as previously suggested by Baumrucker et al. (2016) for cows with a prolonged period of colostrogenesis.

\section{Variation in Quarter Milk Yield and IgG Concentration During the First 5 Milkings}

In all mammary gland quarters, milk yield increased and $\operatorname{IgG}$ concentration decreased during the first 5 milkings after parturition (Figures $1 \mathrm{~A}$ and $\mathrm{B}$ ). The slight decrease in quarter milk yields from the first to the second milking over all cows can be explained by the variable time interval between these milkings (210-1,110 min) because milk yields of the second milking depend on the milking interval between the first and the second milking $(P<0.0001)$. This further indicates that quarters were milked completely empty when harvesting first colostrum and that residual milk did not account for more yield of the second milking at scheduled milking times. Furthermore, hourly milk production between the first and the second milking is still relatively low (Figure 1D), and thus a steep increase in milk yield from the first to the second milking was not expected. The marked increase in milk production starting at the third milking (Figure 1D) coincides with the time relative to parturition as reported by Kessler et al. (2014), where copious milk production takes off.

We previously reported that quarter position was not associated with colostral IgG concentration (Baumrucker et al., 2014a; Gross et al., 2016, 2017), thus emphasizing the differential secretory capacity of each individual quarter. Distribution of first colostrum yield among quarters in the present study revealed an increased amount only in the hind right gland compared with the 3 other quarters (Figure 1C), whereas earlier we observed a higher yield in both hindquarters at the first milking (Gross et al., 2016). Beginning at the second milking, the distribution of milk yield between quarters within cows resulted in an increased allocation toward the hindquarters (Figure 1C). Furthermore, with progressing number of milkings relative to parturition and the start of copious milk secretion, the hindquarters gradually produced more milk than the front quarters (Figure 1A), likely due to their greater cistern area and cisternal and alveolar milk volume (Ayadi et al., 2003). On the contrary, differences in IgG concentrations among quarters persisted throughout the first 5 milkings after calving despite the declining pattern (Figure 1B). Thus, during the period of blood-milk barrier closure, the cessation of the IgG transfer into milk occurs at a different rate in each quarter.

To assess the degree of correlation and agreement in repeatability of milk yield and IgG concentration at the quarter level within a cow over the first 5 successive milkings after parturition, we determined the ICC (Table 2). Hence, the ICC was higher for quarter IgG concentration than for quarter milk yield (0.79 and 0.64 , respectively; Table 2), indicating that the decrease in IgG concentrations occurred with less variation among quarters within cows than the increase in milk yield. Cows entering their second lactation had a lower ICC for milk yield but a higher ICC for IgG concentration compared with older cows (Table 2). Therefore, distribution of quarter milk yield within the same animal during the first 5 milkings showed a broader variation in second-lactation cows, suggesting that the development of the mammary gland is still ongoing. The finding that quarter distribution of milk yield is flexible during at least the first 5 milkings after 
Table 2. Repeatability (intraclass correlation coefficient) of milk yield and total $\mathrm{IgG}$ concentration in quarters within cows during the first 5 milkings after parturition

\begin{tabular}{lccc}
\hline & \multicolumn{2}{c}{$\begin{array}{c}\text { Covariance parameter } \\
\text { estimate }\end{array}$} \\
\cline { 2 - 3 } Item & Cow & Quarter & \multirow{2}{*}{ ICC $^{1}$} \\
\hline Milk yield & & & \\
All cows & 0.4215 & 0.7524 & 0.64 \\
Second parity & 0.6429 & 0.6356 & 0.50 \\
Third parity & 0.2418 & 0.8404 & 0.78 \\
Fourth and higher parities & 0.3078 & 0.8954 & 0.74 \\
Total IgG concentration & & & \\
All cows & 145.62 & 551.63 & 0.79 \\
Second parity & 60.873 & 568.07 & 0.90 \\
Third parity & 186.71 & 591.68 & 0.76 \\
Fourth and higher parities & 92.669 & 474.61 & 0.84 \\
\hline
\end{tabular}

${ }^{1}$ Intraclass correlation coefficient (ICC) $=\sigma_{\text {quarter }}^{2} /\left(\sigma_{\text {cow }}^{2}+\sigma_{\text {quarter }}^{2}\right)$, where $\sigma^{2}=$ covariance parameter.

calving requires special attention in settings of milking equipment suitable for individual quarter milking (e.g., automatic milking systems).

\section{CONCLUSIONS}

Quarter milk yield and IgG concentrations varied not only at the time of first colostrum harvest but also during the successive milkings after calving among cows. Relative distribution of milk yield among quarters at the first milking was not maintained constant up to the fifth milking. Milk production started at an individual rate for each quarter, leading to a greater milk production in the hindquarters at the end of the study period. Additionally, the continuously decreasing IgG concentrations reflecting the cessation of IgG transfer into milk due to the closure of the blood-milk barrier occurred at a different rate in each individual quarter. Our results confirm that mammary quarters are independent glands where processes of colostrogenesis and lactogenesis are not finally set at parturition. Adaptation to and development of milk production likely occurs at an individual quarter level during the first days after calving and beyond.

\section{REFERENCES}

Annen, E. L., C. M. Stiening, B. A. Crooker, A. C. Fitzgerald, and R. J. Collier. 2008. Effect of continuous milking and prostaglandin E2 on milk production and mammary epithelial cell turnover, ultrastructure, and gene expression. J. Anim. Sci. 86:1132-1144. https: //doi.org/10.2527/jas.2007-0726.

Ayadi, M., G. Caja, X. Such, and C. H. Knight. 2003. Use of ultrasonography to estimate cistern size and milk storage at different milking intervals in the udder of dairy cows. J. Dairy Res. 70:1-7. https://doi.org/10.1017/S0022029902005873.

Baumrucker, C. R., A. M. Burkett, A. L. Magliaro-Macrina, and C. D. Dechow. 2010. Colostrogenesis: Mass transfer of immunoglobulin
G1 into colostrum. J. Dairy Sci. 93:3031-3038. https://doi.org/10 .3168/jds.2009-2963.

Baumrucker, C. R., C. D. Dechow, A. L. Macrina, J. J. Gross, and R. M. Bruckmaier. 2016. Mammary immunoglobulin transfer rates following prepartum milking. J. Dairy Sci. 99:9254-9262. https:// doi.org/10.3168/jds.2016-11370.

Baumrucker, C. R., A. Stark, O. Wellnitz, C. Dechow, and R. M. Bruckmaier. 2014a. Short communication: Immunoglobulin variation in quarter-milked colostrum. J. Dairy Sci. 97:3700-3706. https://doi.org/10.3168/jds.2013-7107.

Baumrucker, C. R., R. S. Zbinden, H. A. van Dorland, G. J. Remmelink, B. Kemp, A. T. van Knegsel, and R. M. Bruckmaier. 2014b. Continuous milking of dairy cows disrupts timing of peak IgG concentration appearance in mammary secretions. J. Dairy Res. 81:403-409. https://doi.org/10.1017/S002202991400034X.

Boutinaud, M., J. Guinard-Flament, and H. Jammes. 2004. The number and activity of mammary epithelial cells, determining factors for milk production. Reprod. Nutr. Dev. 44:499-508. https://doi .org/10.1051/rnd:2004054.

Cabral, R. G., C. E. Chapman, K. M. Aragona, E. Clark, M. Lunak, and P. S. Erickson. 2016. Predicting colostrum quality from performance in the previous lactation and environmental changes. J. Dairy Sci. 99:4048-4055. https://doi.org/10.3168/jds.2015-9868.

Capuco, A. V., R. M. Akers, and J. J. Smith. 1997. Mammary growth in Holstein cows during the dry period: Quantification of nucleic acids and histology. J. Dairy Sci. 80:477-487. https://doi.org/10 .3168/jds.S0022-0302(97)75960-5.

Conneely, M., D. P. Berry, R. Sayers, J. P. Murphy, I. Lorenz, M. L. Doherty, and E. Kennedy. 2013. Factors associated with the concentration of immunoglobulin $\mathrm{G}$ in the colostrum of dairy cows. Animal 7:1824-1832. https://doi.org/10.1017/S1751731113001444.

Davis, S. R. 2017. Triennial Lactation Symposium/BOLFA: Mammary growth during pregnancy and lactation and its relationship with milk yield. J. Anim. Sci. 95:5675-5688. https://doi.org/10 $.2527 /$ jas2017.1733.

Dhakal, K., C. Maltecca, J. P. Cassady, G. Baloche, C. M. Williams, and S. P. Washburn. 2013. Calf birth weight, gestation length, calving ease, and neonatal calf mortality in Holstein, Jersey, and crossbred cows in a pasture system. J. Dairy Sci. 96:690-698. https://doi.org/10.3168/jds.2012-5817.

Dunn, A., A. Ashfield, B. Earley, M. Welsh, A. Gordon, and S. J. Morrison. 2017. Evaluation of factors associated with immunoglobulin $\mathrm{G}$, fat, protein, and lactose concentrations in bovine colostrum and colostrum management practices in grassland-based dairy systems in Northern Ireland. J. Dairy Sci. 100:2068-2079. https://doi.org/ $10.3168 / j d s .2016-11724$.

Gross, J. J., E. C. Kessler, V. Bjerre-Harpoth, C. Dechow, C. R. Baumrucker, and R. M. Bruckmaier. 2014. Peripartal progesterone and prolactin have little effect on the rapid transport of immunoglobulin G into colostrum of dairy cows. J. Dairy Sci. 97:29232931. https://doi.org/10.3168/jds.2013-7795.

Gross, J. J., E. C. Kessler, and R. M. Bruckmaier. 2017. Quarter vs. composite colostrum composition assessed by Brix refractometry, specific gravity and visual color appearance in primiparous and multiparous dairy cows. Transl. Anim. Sci. 1:26-35. https://doi .org/10.2527/tas2016.0001.

Gross, J. J., G. Schüpbach-Regula, and R. M. Bruckmaier. 2016. Rapid communication: Colostrum immunoglobulin concentration in mammary quarters is repeatable in consecutive lactations of dairy cows. J. Anim. Sci. 94:1755-1760. https://doi.org/10.2527/ jas.2016-0362.

Gulliksen, S. M., K. I. Lie, L. Sølverød, and O. Østerås. 2008. Risk factors associated with colostrum quality in Norwegian dairy cows. J. Dairy Sci. 91:704-712. https://doi.org/10.3168/jds.2007-0450.

Kamal, M. M., M. Van Eetvelde, E. Depreester, M. Hostens, L. Vandaele, and G. Opsomer. 2014. Age at calving in heifers and level of milk production during gestation in cows are associated with the birth size of Holstein calves. J. Dairy Sci. 97:5448-5458. https:// doi.org/10.3168/jds.2014-7898.

Kehoe, S. I., B. M. Jayarao, and A. J. Heinrichs. 2007. A survey of bovine colostrum composition and colostrum management practices 
on Pennsylvania dairy farms. J. Dairy Sci. 90:4108-4116. https:// doi.org/10.3168/jds.2007-0040.

Kessler, E. C., R. M. Bruckmaier, and J. J. Gross. 2014. Milk production during the colostral period is not related to the later lactational performance in dairy cows. J. Dairy Sci. 97:2186-2192. https://doi.org/10.3168/jds.2013-7573.

Lehmann, M., O. Wellnitz, and R. M. Bruckmaier. 2013. Concomitant lipopolysaccharide-induced transfer of blood-derived components including immunoglobulins into milk. J. Dairy Sci. 96:889-896. https://doi.org/10.3168/jds.2012-5410.

Mayasari, N., G. de Vries Reilingh, M. G. Nieuwland, G. J. Remmelink, H. K. Parmentier, B. Kemp, and A. T. van Knegsel. 2015. Effect of maternal dry period length on colostrum immunoglobulin content and on natural and specific antibody titers in calves. J. Dairy Sci. 98:3969-3979. https://doi.org/10.3168/jds.2014-8753.

Morin, D. E., S. V. Nelson, E. D. Reid, D. W. Nagy, G. E. Dahl, and P. D. Constable. 2010. Effect of colostral volume, interval between calving and first milking, and photoperiod on colostral IgG concentrations in dairy cows. J. Am. Vet. Med. Assoc. 237:420-428. https://doi.org/10.2460/javma.237.4.420.

Morrill, K. M., E. Conrad, A. Lago, J. Campbell, J. Quigley, and H. Tyler. 2012. Nationwide evaluation of quality and composition of colostrum on dairy farms in the United States. J. Dairy Sci. 95:3997-4005. https://doi.org/10.3168/jds.2011-5174.

Norman, H. D., J. R. Wright, M. T. Kuhn, S. M. Hubbard, J. B. Cole, and P. M. VanRaden. 2009. Genetic and environmental factors that affect gestation length in dairy cattle. J. Dairy Sci. 92:22592269. https://doi.org/10.3168/jds.2007-0982.

Quigley, J. D., and J. J. Drewry. 1998. Nutrient and immunity transfer from cow to calf pre- and postcalving. J. Dairy Sci. 81:2779-2790. https://doi.org/10.3168/jds.S0022-0302(98)75836-9.
Rothenanger, E., R. M. Bruckmaier, and J. W. Blum. 1995. Association and dissociation of single quarter and total milk flow in dairy cows: Effects of milking with and without pre-stimulation. Milchwiss 50:63-67.

Rothschild, M. F., G. W. Bodoh, R. E. Pearson, and R. H. Miller. 1980. Sources of variation in quarter milk flow measures. J. Dairy Sci. 63:1138-1144.

Samarütel, J., C. R. Baumrucker, J. J. Gross, C. D. Dechow, and R. M. Bruckmaier. 2016. Quarter variation and correlations of colostrum albumin, immunoglobulin G1 and G2 in dairy cows. J. Dairy Res. 83:209-218. https://doi.org/10.1017/S0022029916000091.

Shoshani, E., S. Rozen, and J. J. Doekes. 2014. Effect of a short dry period on milk yield and content, colostrum quality, fertility, and metabolic status of Holstein cows. J. Dairy Sci. 97:2909-2922. https://doi.org/10.3168/jds.2013-7733.

Watters, R. D., J. N. Guenther, A. E. Brickner, R. R. Rastani, P. M. Crump, P. W. Clark, and R. R. Grummer. 2008. Effects of dry period length on milk production and health of dairy cattle. J. Dairy Sci. 91:2595-2603. https://doi.org/10.3168/jds.2007-0615.

Weaver, D. M., J. W. Tyler, D. C. VanMetre, D. E. Hostetler, and G. M. Barrington. 2000. Passive transfer of colostral immunoglobulins in calves. J. Vet. Intern. Med. 14:569-577.

\section{ORCIDS}

E. C. Kessler ๑ https://orcid.org/0000-0003-0359-1136

G. C. Pistol (๑ https://orcid.org/0000-0003-1139-604X

R. M. Bruckmaier ( ) https://orcid.org/0000-0002-9374-5890

J. J. Gross (๑) https://orcid.org/0000-0002-2578-6076 